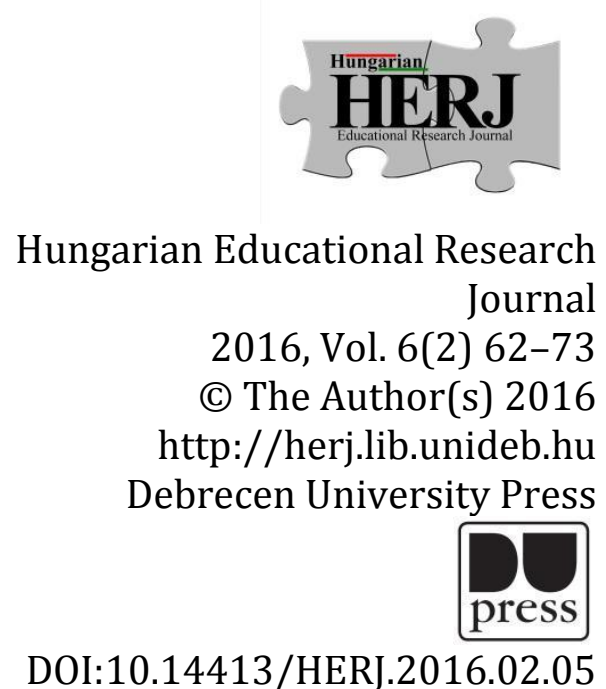

Transitions in Croatian pre-tertiary education and teacher education since independence

Vlasta Vizek Vidović12 \& Vlatka Domović13

DOI:10.14413/HERJ.2016.02.05

\begin{abstract}
The aim of this paper is to give an overview of developments in Croatian pre-tertiary and teacher education since 1991. The starting point is a brief presentation of the country context in the transition period from socialist to democratic society. The developments in pre-tertiary education have been analysed in two periods - from 1990 to 2000, and from 2001 to the present moment. The main strategic documents are presented and their implementation is discussed. The reform of the system of initial teacher education is elaborated in terms of three concepts upgrading, standardization, and professionalization. The implications of the implementation of these concepts for structural and curricula changes are problematised. In addition, a third theme, that of educational research, has been introduced in order to present the interconnectedness between educational transitions and educational research.
\end{abstract}

Keywords: educational reform, pre-tertiary education, teacher education, education research

\footnotetext{
12 Vlasta Vizek Vidović, Institute for Social Research in Zagreb (Croatia).vvizek@idi.hr

13 Vlatka Domović University of Zagreb, Faculty of Teacher Education, Zagreb (Croatia). vlatka.domovic@ufzg.hr
} 


\section{Country context}

Croatia is one of the smaller European Union countries with a territory of about 55,000 square kilometres and 4,284,889 inhabitants according to the 2011 census. Regarding its ethnic composition, Croatia is a highly homogenous country with 3,874,321 (90.42 \%) inhabitants declared as Croats and 410,568 (9.58\%) declared as members of national minorities (Statistical Yearbook of the Republic of Croatia, 2014). Although the data about ethnic composition indicate ethnic homogeneity of the Croatian society this does not mean Croatia is a culturally uniform country. From the socio-political perspective two traditions have influenced Croatian culture and life in general. Continental Croatia is closer to the Central European circle due to the fact that it was part of the Habsburg Empire since the early $16^{\text {th }}$ century, while the coastal region is closer to the Mediterranean cultural circle due to the long-lasting connections with the Republic of Venice (Godler \& Domović, 1999).

In the recent past, two milestones have had the most important role in shaping the Croatian educational context. The first one was Croatia gaining its independence in 1991, and the second one was the country becoming member of the European Union in 2013. These two events brought about changes in the political, economic and social system, emphasising ideas of liberal democracy, political pluralism, privatisation of economy and civil society (Prpić, 1993). In the 1990s, Croatia partly shared the experience of other Eastern European countries in the transition from socialist to capitalist economy. On the other hand, the change of political status from being part of the former Yugoslavia to becoming an independent state was marked by the Croatian War of Independence, lasting from 1991 to 1995. The post-war transition period was burdened with the material destruction of one third of the territory combined with a negative demographic trend in general, a high unemployment rate, a large number of people who got early retirements, and a very unfavourable educational structure. The generally unfavourable situation has been aggravated by psychological factors such as high expectations and hopes that changes of formal political and institutional changes would lead to social and economic welfare (Domović \& Vizek Vidović, 2015).

\section{Transition in pre-tertiary education}

\section{Period $1990-2000$}

Two distinct periods could be identified in the educational transitions since 1990, one lasting from 1990 to 2000 and the other from 2001 until the present. The first five postwar years can be marked as damage alleviation as the focus was on the reparation of 
physical infrastructure as $33 \%$ of schools were heavily damaged during the war, and Croatia was coping with 386264 displaced persons in 1995 (Perković \& Puljiz, 2001). After the war, the major task was to rebuild the infrastructure in terms of improving material conditions and human resources. At that time, the civil sector educational organisations played an important role for teacher professional development,offering psychological assistance to teachers and students as well as introducing new themes such as civic education, intercultural education, and a student-centred approach to teaching and learning.

At the same time, the legislative ground for the whole educational system was laid down with the adoption of key acts on education: the Elementary School Act in 1990; the Secondary School Act in 1992; the Act on Scientific Activity and Higher Education in 1993; and the Preschool Education Act in 1997.

The structure of pre-tertiary education remained firmly rooted in the mid-20 ${ }^{\text {th }}$ century model of lower- and upper-primary school with four grades of classroom teaching, followed by four grades of subject teaching. Secondary education also did not change, with four year of comprehensive schools (gymnasiums) and three- and four-year vocational schools. The schools were operating mainly according to the pre-war curriculum with some adjustments to the new political context regarding social science and humanities subjects with major emphasis on the national context, and the introduction of religious education as an elective subject. So, in the new secondary school curricula an ideological shift could be observed in that some school subjects, such as Marxism and Socialist Self-Management, People's Defence and Social Self-Protection, Production and Technical Education, were abandoned and new subjects, such as Politics and Economy and Ethics and Culture, were introduced (Baranović, 2008).

\section{Period $2001-2015$}

The period from 2001 to the present can be perceived as a continuous state of change. The focus of policy makers and educational experts was on curriculum modernisation and teacher education reform. Major structural changes were discussed, such as nineyear elementary school and new models of vocational education, but without achieving consensus between policy makers and stakeholders.

In the year 2001 the White Paper on Croatian Education was created, intended to serve as the basis for the comprehensive transformation of the Croatian educational system (Pastuović, 2001). The aim of the proposed reform was the improvement of efficiency of the educational system through the following changes: transition to a six-year elementary school; introduction of nine-year compulsory education; modernisation of the curriculum; education of teachers for a six-year elementary school; introduction of 
state examinations based on external evaluation; reform of the university system in accordance with the Bologna Declaration; decentralisation of financing and management of the educational system. The White Paper was not further elaborated into educational strategy as was initially planned.

Besides the attempt to outline a general education reform, in the period from 2000 to 2005 specific concerns were raised regarding the educational values of inclusion and social cohesion. These issues were articulated in two policy documents, the Law on Education in Languages and Letters of National Minorities (2000) and the Constitutional Act on the Rights of National Minorities (2002), which promote the integration of national minorities into the Croatian society with guarantees of preservation of their ethnic, cultural, linguistic and religious identity (Tatalović, 2006). Pupils and their parents can choose between three options: being educated in their mother tongue and script; attending bilingual classes or nurturing their language and culture in extracurricular classes (Domović et al., 2013).

The second attempt to introduce a holistic approach to educational changes was described in a new strategic document - the Education Sector Development Plan 20052010 (2005). The priorities stated in that document were similar, with greater emphasis on teacher education and their continuous development, on strategies for improving the management and efficiency of the education system and on achieving greater social cohesion through education. The implementation of the Sector Development Plan 20052010 was accompanied with extensive change of education legislation, such as the Act on Education in Primary and Secondary Schools (2008), the National Pedagogical Standard for the Elementary School (2008), and the Vocational Education Act (2009).

In the period 2004-2007 the necessary infrastructure for steering educational reforms and the quality assurance of the whole educational sector was developed with special focus on mechanisms for the external evaluation of education. In 2004, the National Centre for External Evaluation of Education (Act on Establishment of National Centre for External Evaluation of Education, 2004) was established with the task of implementing various external evaluation measures for pre-tertiary education, followed by the National Agency for Science and Higher Education in 2009 (Act on Quality Assurance in Science and Higher Education, 2009) with the task of monitoring and evaluating the quality of higher education institutions and public research institutes.

In the same period, policy makers, educational practitioners and experts got involved in the process of developing new school curricula with major focus on alleviating pupils' workload and enhancing learner-centred teaching and learning. In order to fulfil that task, extensive preparations started which resulted with the document Strategy for the Construction and Development of the National Curriculum for Pre-School Education, 
General Compulsory and Secondary Education (2007). That document was a precursor to the National Curriculum Framework for Pre-school Education and General Compulsory and Secondary Education (NCF), which was finalised in 2010. The starting point for the development of the NCF was the European Key Competences Framework for Lifelong Learning (2007) as well as a learning outcome approach. The goals of the NCF were summarised as follows „The basic characteristic of the National Curriculum Framework is a transition to a system based on competence and student achievement (learning outcomes), unlike the previous one, which focuses on content. .... The National Curriculum Framework instructs teachers to overcome subject specialisation, and to take part more or less equally in developing students' core competences by applying the principle of shared responsibility - in particular by making explicit the values that are intertwined with cross-subject (cross-curricular) topics" (2010: 9). The introduction of cross-subject topics is one of the major curricular innovations as compared to the previous strategic documents. The cross-curricular themes have been defined as follows: Personal and social development; Health, Safety and environmental protection; Learning to learn; Entrepreneurship; Use of ICT; Civic education.

The NCF turned out to be another huge project involving a great number of educational experts and practitioners, that got to the level of formal adoption by the Croatian Government but was not further operationalised and implemented in the teaching practice.

Most recently, the Strategy of Education, Science and Technology - New Colours of Knowledge (Strategy) was formally adopted (2014). The part of the Strategy covering pre-tertiary education has been elaborated through eight topics: development of capacity enhancement of educational institutions; implementation of comprehensive curricular reform, change of primary education structure, rising the quality of work and the social status of teachers, improvement of educational institutions leadership, development of comprehensive student support services, securing optimal work conditions of educational institutions. The implementation of the Strategy has started with the project of comprehensive curricular reform in which more than three hundred educationalists have been engaged on a full-time basis. This work is in progress and the first results are expected in six months.

The overview of the developments in the pre-tertiary educational sector in the last twenty five years reveals that, in spite of various attempts on policy level and strategic documents development, only fragmented and limited interventions have been implemented (e.g. minority education; relinquishment of some school subjects and their replacement with new ones; state exam at the end of secondary education) without major structural and curricular reforms. 


\section{Teacher education 2001 - 2015}

Croatian initial teacher education has been significantly transformed due to the implementation of the Bologna process across higher education. This external pressure has been used as an opportunity for rethinking the structure and approaches to teaching and learning at institutions for teacher education. The processes in teacher education which started in 2005 with the introduction of new curricula could be described in three words: upgrading (from secondary to postsecondary, higher education level), standardization, and professionalization.

\section{Teacher education as part of the higher education system}

In Croatia, there are different categories of teachers depending on the educational level at which they teach: teachers in grades 1 to 4 of primary school (class-teachers), subject teachers in grades 5 to 8 of primary school, subject teachers in secondary academic schools (gymnasium), teachers of general education subjects in secondary vocational schools, and teachers of vocational subjects in secondary vocational schools. In the preBologna period the education of each of these categories differed significantly. The greatest difference was in the type of institutions in which prospective teachers were educated. Primary teachers were educated at higher professional schools which were usually outside the university. Upper-primary and secondary school teachers (subject teachers) were educated at university level.

Debates preceding restructuring the initial teacher education system led to a consensus between policy makers and teacher educators that all institutions responsible for teacher education should be integrated into universities as faculties. Consequently, programmes for primary teachers were transformed into university programmes. In that way, dualism in the education of primary and subject teachers was overcome as now all programmes last five years and a Master's degree is compulsory for all categories of school teachers to enter the profession. Teachers of vocational subjects in secondary schools who get their Master's degree in other professional fields are required to take an extra year of study in order to obtain teaching qualifications (Domović \& Vizek Vidović, 2011).

However, the model of studying differs between class teachers and subject teachers as the program for class teachers (grade 1 to 4 of primary school) is organised according to the simultaneous model while subject teachers are educated according to the consecutive model.

The simultaneous model implies a curriculum designed according to the integrated model of undergraduate and graduate level (5 years, 10 semesters, 300 ECTS) and it is 
delivered at faculties of teacher education. On the other hand, study programs for subject teachers are organised in two cycles - BA level (180 ECTS credits) and MA level (120 ECTS credits) at the faculties for specific academic disciplines. At the BA level, students mostly take two disciplines (academic subjects or majors), while educational studies, teaching methodologies and teaching practice are studied at the master's level (Domović \& Vizek Vidović, 2011).

It has been observed that the universitation of study programmes for primary school teachers has some benefits, but also drawbacks. The main benefit is equal educational status of all categories of teachers. It seems that upgrading the status of institutions responsible for primary teacher education has made them more attractive for secondary school graduates from more prestigious secondary schools and with better school achievements. Also, in terms of curriculum content, several courses related to academic disciplines (subjects) as well as ICT and educational research methodology have been included. On the other hand, the scope of educational sciences and school practice has remained the same or even has been decreased. It opens the new debate about the quality of teaching competences acquired in initial teacher education. The universitation of primary teacher initial education has also put more pressure on teacher educators for attaining high research productivity, which has somewhat shifted focus from teaching and supporting students' learning.

\section{Standardisation of teacher education}

The responsibility for designing pre-Bologna teacher education programmes was fully in the domain of faculties or departments as autonomous agents with an orientation towards discipline-based curricula and content-centred teaching. The introduction of the concept of learning outcomes and student-centred teaching raised the awareness of curriculum designers and teacher educators for more inter-institutional cooperation. One of the important steps in that direction was the provision of the Act on Elementary and Secondary Schools (2008) which stipulated that teacher professional competences should be acquired through programmes with a minimum of 60 ECTS credits.

The harmonisation of teacher education programmes was further enhanced by the process of reaccreditation of higher education institutions conducted by the Agency for Science and Higher Education. The reaccreditation reports, which were made public, enabled institutions to compare their functioning and achievements.

The most recent development which supports standardisation and harmonisation in teacher education is the introduction of the Act on Croatian Qualification Framework (CQF) (2013) which recommends the development of occupational and qualification standards for all professions including the teaching profession. The CQF steers higher 
education institutions to systematically apply a learning outcomes approach as a basis for curriculum planning. In order to implement the CQF, the Croatian Ministry of Science, Education and Sports opened a project line for defining qualification standards for various programmes and adjusting curricula to the defined standards. Several projects aimed at defining qualification standards for teacher education programmes have started, involving teacher education faculties from different universities. The main goal of these projects is to define qualification standards in terms of learning outcomes which will represent the common core competences for all involved programmes.

\section{Teacher education and teacher professionalization}

As mentioned earlier in the Strategy of Education, Science and Technology - New Colours of Knowledge (Strategy) (2014), one of the strategies for pre-tertiary education is rising the quality of work and social status of teachers. Among the measures for the realisation of this goal is the professionalization of the teaching occupation. Professionalization has been described as the realisation of the following conditions: general awareness of teachers' work as socially valuable and enjoying high social status; high level of specific knowledge and skills which enables teachers for autonomous decision-making in complex situations; acquisition of professional competences through a long period of initial university education followed by a formal induction period ending with an exam for full licence; lifelong competence development based on formal continuous professional development and informal learning and periodical evaluation of competences (re-licensing); programmes for initial teacher education which, besides professional knowledge and skills, enhance acquiring professional values and building teacher professional identity; establishment of professional associations which regulate, by means of a code of ethics and other acts, the criteria for entering a profession and professional practice. These conditions are further operationalised through several measures, such as: the development of national competence standards for teachers and a code of ethics, development of a comprehensive model of induction and teacher licensing, attracting the best candidates for teacher studies and the retention of the best teachers in the profession.

The 'universitation' of teacher initial education can be recognised as an important part of the professionalization process combined with the introduction of internal and external quality assurance mechanisms. Another important issue regarding professionalization is the further improvement of the induction process and the development of a licensing system. In order to start these developments, the project Development of the national qualification standard for teachers as a basis for the implementation of a teacher licensing system (www.nskzaucitelje.hr/eng) was carried out, which resulted with the proposal of national qualification standards. 
The professionalization of the teaching occupation in the way envisioned in the Strategy should be a joint endeavour of different key stakeholders. At this moment, the academic community and educational experts are leading the implementation of some concrete activities, but for the full realisation of this goal more support from other stakeholders, such as policy makers, teacher unions, and professional teacher associations is required.

\section{Educational research supporting transitions in pre-tertiary and teacher education}

During the early transition period, several significant trends could be observed within the educational research community. In the pre-transition era, educational research was mainly concentrated within pedagogy departments at faculties of humanities and social sciences, while teacher education colleges outside universities were marginalized as they were strongly teaching-oriented institutions. At university departments, some educational research was also carried out, mainly by psychology departments, while teachers who taught teaching methodology courses were not encouraged to do educational research as they could get their doctoral degrees only in the area of their basic academic discipline.

At the beginning of the 21st century, the Bologna process and EU initiatives regarding the tuning of educational structures in higher education strengthened the awareness of a need to start interdisciplinary educational research with stronger networking between research institutions. These synergic efforts have resulted in the formal recognition of educational sciences as a distinct interdisciplinary area, allowing for the implementation of postgraduate studies. The other accomplishment in this area has been the establishment of the Centre for Educational Research and Development (CERD), a specialised research unit at the Institute for Social Research in Zagreb in 2003. Starting several lines of research, CERD has become the stronghold of educational research in the areas of curriculum development, teacher education and professional development, the social dimension in higher education and self-evaluation and external evaluation of pretertiary education. Moreover, certain trends can be observed regarding specific research orientations among institutions conducting educational research. For instance, a comparison of work done at the three most prominent departments of psychology (in Zagreb, Zadar and Rijeka) shows that at the University of Zagreb research focuses on learning mathematics and science, at the University of Rijeka it focuses on learning reading and writing, and at the University of Zadar on motivation to learn.

The process of tertiary teacher education resulted in lively research activities at the institutions which prior to that were not eligible to participate in state-funded research in educational sciences, especially in various teaching methodologies. An important contribution to educational research has been made by establishing doctoral studies at the Faculty of Teacher Education and also by renovating doctoral studies at the 
Department of Pedagogy at the University of Zagreb, which has strengthened interdisciplinary research in educational sciences. These doctoral studies have supported doctoral students to research some new topics, such as early education, multicultural education, civic education, school climate and culture.

Furthermore, in order to support the cooperation and networking of educational researchers, in 2012 the meeting point for educational researchers was established as a biannual conference called Days of Educational Sciences, and, in 2014, the Croatian Educational Research Association (CERA) was founded, and in 2015 it become member of the European Educational Research Association. This is a new opportunity for educational researchers to network and cooperate in the country and abroad.

\section{Conclusions}

In the analysed period, the changes in pre-tertiary education started with laying down the legislative basis for the educational reform. The acceleration of changes occurred after 2001 with the White Paper which outlined the key goals shaping the further developments at policy level. However, due to the chronic financial lacks of the educational sector and insufficient human resources and institutional capacities, the reforms were only partially implemented as intervention measures for some concrete problems.

One of the hindrances to the implementation of a comprehensive educational reform might be the fragmentation of efforts of different stakeholders, even mutual mistrust, as well as discontinuity in the governing of the educational sector, sometimes with periods without clear goals or priorities for education. It also should be noted that the educational sector was the one with the highest rate of fluctuation of ministers, who on average stayed in their position 1.5 years (20 ministers of education since 1990).

The latest Strategy of Education, Science and Technology (2014), as an attempt to link all three areas in order to join the efforts of key stakeholders in raising quality in education, research and innovations as major drivers of socio-economic development, was received with mixed feelings in the academic community. It has been positively evaluated in a public debate, because of its comprehensiveness, underlying expertise, and operationalisation of concrete measures, but the question remains open whether there will be sufficient financial and human resources and institutional capacities for its implementation in the planned time frame (Domović \& Vizek Vidović, 2015).

Teacher education underwent significant structural changes during the last decade due to the general transformation of higher education instigated and inspired by the Bologna process. In our opinion, the greatest positive change has been the abandonment of 
dualism in education of primary class teachers and subject teachers. An important step forward in designing curricula has been the implementation of a learning-outcomesbased approach and the promotion of student-centred teaching. One of the challenges for a change of paradigm in teaching and learning at teacher education institutions are often insufficient teaching competences of university teacher educators. That is why, a debate about improving the competences of teacher educators has recently been opened at most institutions.

Until recently, educational research has been a relatively neglected field, compartmentalised within specific areas (e.g. educational psychology, sociology of education, subject teaching methods). The raised awareness of a need for researchinformed educational policies as well as the inclusion of educational sciences into the corpus of formally recognised fields of science gave a new momentum for networking and cooperation of researchers in interdisciplinary research.

\section{References}

Act on Croatian Qualification Framework (Zakon o Hrvatskom kvalifikacijskom okviru). (2013). Zagreb: Narodne novine 22/13.

Act on Elementary and Secondary Schools (Zakon o odgoju i obrazovanju u osnovnoj i srednjoj školi). (2008). Zagreb: Narodne novine 87/08.

Act on Establishment of National Centre for External Evaluation of Education (Zakon o osnivanju Nacionalnoga centra za vanjsko vrednovanje obrazovanja.(2004). Zagreb: Narodne novine $151 / 04$.

Act on Quality Assurance in Science and Higher Education. (Zakon o osiguravanju kvalitete u znanosti i visokom obrazovanju). (2009). Zagreb: Narodne novine 45/09.

Act on Scientific Activity and Higher Education (Zakon o znanstvenoj djelatnosti i visokom obrazovanju). (2003). Zagreb: Narodne novine 123/03.

Baranović, B. (2008). Promjene obrazovnog diskursa u postsocijalističkoj Hrvatskoj. In: Pilić, Š. (Ed.) Obrazovanje u kontekstu tranzicije. Biblioteka Školskog vjesnika: Split. 149 - 164

Constitutional act on the rights of national minorities (Ustavni zakon o pravima nacionalnih manijina. (2002). Zagreb: Narodne novine 155/02.

Domović, V. and Vizek Vidović, V. (2011). Recent developments in teacher education in Croatia (2005 2010). In Zuljan, M. V. and Vogrinc, J. (Eds.). European Dimensions of Teacher Education Similarities and Differences. Ljubljana: Faculty of Education; Kranj: The National School of Leadership and Education, 253 - 270.

Domović, V., Gehrmann, S., Knežević, Ž., Oreški, P., Petravić, A., Šimović, V. \& Vican, D. (2013). Lehrerbildung in Kroatien - Perspektiven und Entwicklung. In: Domović, V., Gehrmann, S., KrügerPotraz,M., Helmchen, J. \& Petravić, A. (Eds.) Europäische Lehrerbildung. Annäherung an ein neues Leitbild. Münster: Waxmann, 135 - 172. 


\section{HERJ Hungarian Educational Research Journal, Vol 6 (2016), No 2}

Domović, V. \& Vizek Vidović, V. (2015). Croatia: An Overview of Educational Reforms, 1950-2014. In: Corner, T. (Ed.) About Education in the European Union: Post-2003 Member States. London: Bloomsbury. $27-40$.

Education Sector Development Plan 2005-2010. (2005). Zagreb: Ministry of Science, Education and Sports.

Elementary school act (Zakon o osnovnom školstvu). (1990). Zagreb: Narodne novine 50/90.

European key competences framework for lifelong learning - European Reference Framework. (2007). Luxembourg: Office for Official Publications of the European Communities.

Godler, Z. \& Domović, V. (1999). Clear Needs, Uncertain Responses: Change in the Croatian Education System. In: Mazurek, K., Winzer, M. A. \& Majorek, Cz. (Eds), Education in a global society: a comparative perspective. Needham Heights, MA: Allyn and Bacon. $271-284$.

Law on education in the language and script of national minorities (Zakon o odgoju i obrazovanju na jeziku i pismu nacionalnih manjina). (2000). Zagreb: Narodne novine 51/00, 56/00.

National Curriculum Framework for Pre-school Education and General Compulsory and Secondary Education. (2010). Zagreb: Ministry of Science, Education and Sports.

Pastuović, N. (Ed.) (2001). White Paper on Croatian Education. Zagreb: The Government of the Republic of Croatia.

Perković, M. \& Puljiz, V. (2001). Ratne štete, izdaci za branitelje, žrtve i stradalnike rata u Republici Hrvatskoj. Revija za socijalnu politiku. 8 (2), 235 - 238.

Preschool Education Act (Zakon o predškolskom odgoju i obrazovanju). (1997). Zagreb: Narodne novine $10 / 97$.

Prpić, I. (1993). Communism and nationalism. In: Puhovski at al. (Eds.) Politics and Economics in Transition. Zagreb: Informator.

Secondary school act (Zakon o srednjem školstvu). (1992). Zagreb: Narodne novine 19/92.

Statistical Yearbook of the Republic of Croatia (Statistički ljetopis Republike Hrvatske). (2014). Retrieved: December, 7th, 2015, from: http://www.dzs.hr/Hrv_Eng/ljetopis/2014/sljh2014.pdf

Strategy for the Construction and Development of the National Curriculum for Preschool Education, General Compulsory and Secondary School Education. (2007). Zagreb: Ministry of Science, Education and Sport.

Strategy of education, science and technology - New colours of knowledge (Strategija obrazovanja, znanosti i tehnologije - Nove boje znanja). (2014). Zagreb: Ministarstvo znanosti obrazovanja i sporta.

Tatalović, S. (2006). National Minorities and Croatian Democracy. Politička misao, XLIII (5), 45 - 59.

Vocational Education Act (Zakon o strukovnom obrazovanju). (2009). Zagreb: Narodne novine 30/09. 